\title{
Perceived Problems of Being an Accounting Teacher ${ }^{\star}$
}

Tamires Sousa Araújo

Master's Student, Graduate Program in Accounting, Federal University of Uberlândia

E-mail: tamiresousa124@hotmail.com

Francielly Dornelas Correia Lima

Undergraduate Student, College of Accounting, Federal University of Uberlândia

E-mail: franciellydornelas@hotmail.com

Ana Clara Lacerda de Oliveira

Undergraduate Student, College of Accounting, Federal University of Uberlândia

E-mail: anaclaracontabeis@hotmail.com

Gilberto José Miranda

Ph.D Professor; Graduate Program in Accounting, Federal University of Uberlândia

E-mail: gilbertojm@facic.ufu,br

Received on 12.06.2013-- Desk acceptance on 01.03.2014 - $3^{\text {rd }}$ version accepted on 12.11.2014

\section{ABSTRACT}

This study aims to identify the primary problems faced by accounting professors both upon entry into the profession and during later phases. Thus, it seeks to answer the following research question: what are the problems perceived by accounting professors in Brazil during each phase of the professional life cycle? The data collection instrument was constructed based on the life cycles proposed by Huberman (2000) and the problems identified by Veenman (1984) and validated by a committee of experts. (Delphi technique). The sample consisted of 574 Brazilian professors. The results indicate that the main problems faced by professors were the following: "lack of student mótivation"; "heterogeneous classes"; "amount of administrative work"; "very large class size"; and "lack of time". It was also found that these problems tend to be the same during all phases of the professorial life cycle. However, these problems are more intense upon entry into the career; their importance decreases in each phase. It was also found that professors working for public versus private institutions confronted different problems. The large amount of administrative work and the lack of guidance by the higher education institution (HEI) are typical problems of public institutions. The degree level achieved by professors is also sensitive to the type of problems that they face. In other words, the lack of opportunities for additional training, the lack of HEI guidance, and the knowledge of academic standards are issues that most directly affect professors with lower professional degrees, whereas the lack of time and the large amount of administrative work are problems faced with greater intensity by professors with higher degrees.

Keywords: higher education, life cycle, professors, accounting, Brazil. 


\section{INTRODUCTION}

Higher education in Brazil has experienced major changes in recent years. According to data from the National Census of higher education, the number of students enrolled in 1962 was 107,509. That number jumped to $6,741,700$ in 2011 , i.e., in 50 years, there was an approximately 62 -fold increase in the number of students enrolled in higher education. The Brazilian population did not triple during the same period.

Furthermore, according to the National Education Census, during those five decades, the private sector has also expanded its share of the total number of enrollments. In $2011,72 \%$ of higher-education enrollments were offered by the private sector. In addition, distance learning is assuming an important role in student enrollment. In 2011 , approximately $15 \%$ of students were enrolled in distance learning courses. In short, the expansion experienced in the past five decades, combined with the processes of inclusion and quotas, contributed to an increase in the diversity in Brazilian classrooms in terms of social class, ethnicity, gender, age, creed, learning styles, etc. (Zabalza, 2007; Cunha \& Pinto, 2009; Miranda, 2011).

This changing scenario has been accompanied by problems related to the consolidation of higher education in Brazil. Major challenges include training professors to welcome new students according to their different educational needs training because student diversity is increasing, demanding professorial skills in properly managing differences in the teaching and learning processes.

In the study of the training of accounting professors, it is important to know the phases of professors' professional lives. The Huberman (1989) study is a classic of the educational literature because it identifies the phases of teachers' professional lives. Another important aspect of teacher education is to understand the main problems that affect teaching. The Veenman (1984) study is another education literature classic because the author identifies teachers' main problems in several countries as described by studies published between 1960 and 1984. Although these two authors focused more closely on teaching at the primary and secondary levels, their findings can provide important insights into teaching at higher levels.

In recent years, accounting programs have experienced virtually all of the changes in university education overall, in addition to changes particular to the accounting profession, such as the adoption of international accounting standards and the expansion of graduate courses that began in 1998, resulting in the need for investigations to shed light on how to improve teacher education gene- rally and the teaching of accounting in particular.

Thus, this study poses the following research question: "What are the main problems perceived by accounting educators in their role as professors in Brazil?". This question leads to the following general objective: to identify the main problems faced by professors in the entry and later phases of their careers. To achieve this overall objective, the following specific objectives were established: (i) identify the main problems confronted by the professors participating in this study; (ii) identify the most significant problems that afflict accounting professors along the phases of the professional life cycle; (iii) assess whether there are significant differences in the problems that affect professors according to type of institution (public or private); and (iv) assess whether a professor's degree level has some influence on his or her perception of problems.

According to Veenman (1984), integrating existing studies on professors' concerns over time with a study on the problems perceived by professors in the various phases of their professional life cycles may help teacher training programs to choose more appropriate content and strategies. In the accounting field, such studies are even more relevant due to the lack of studies of this nature, because no study with a specific focus on life cycle and problems faced by accounting professors has been identified in the literature.

In addition to the lack of studies on this subject, knowing the problems faced by professionals who choose academia is important the prior knowledge of such problems enables the discussion and implementation of solutions. Identifying these problems also highlights the potential to find solutions to improve education in the accounting field to meet the needs of such professionals throughout their careers.

Finally, it seems that teaching different areas of knowledge requires distinct epistemological studies according to each subject's peculiarities (Pierre, Wilson, Ravenscroft, \& Rebele, 2009). This study, which addresses the professional life-cycle phases of professors and the problems presented to them during each phase, aims to improve teaching in the accounting area in light of differences among institutions (public and private) and the professors' level of education, among professors' other difficulties.

In addition to the matters discussed in this introduction, this study contemplates a discussion of the professorial life cycle and an analysis of studies of the problems perceived by professors in their jobs, the method used for this study, the results, and final considerations. 


\section{THEORETICAL FRAMEWORK}

\subsection{Professional Life Cycle.}

The study of the professional life of a given area makes it possible to identify the paths taken, the possibilities offered by the profession, its difficulties, its potential, and its opportunities, because the human life cycle is significantly reflected in every step the professional takes. In teaching, this type of study is essential to understand the professional's career and to seek both teaching alternatives and better working conditions (Nóvoa, 1992).

Huberman's (1989) Swiss study has become a reference for scholars wishing to explore different aspects of teachers' professional life cycles. The study was conducted with 160 secondary teachers and identified the main phases of teachers' professional careers; it is useful for understanding the perceptions of teachers along the life cycle.

According to Huberman, the professional education career involves several phases, beginning with training and moving to career entry, professional stabilization, and later phases. Huberman (2000, p. 38) states, "The development of a career is thus a process and not a series of events". This process consists of several phases, as shown in Figure 1.

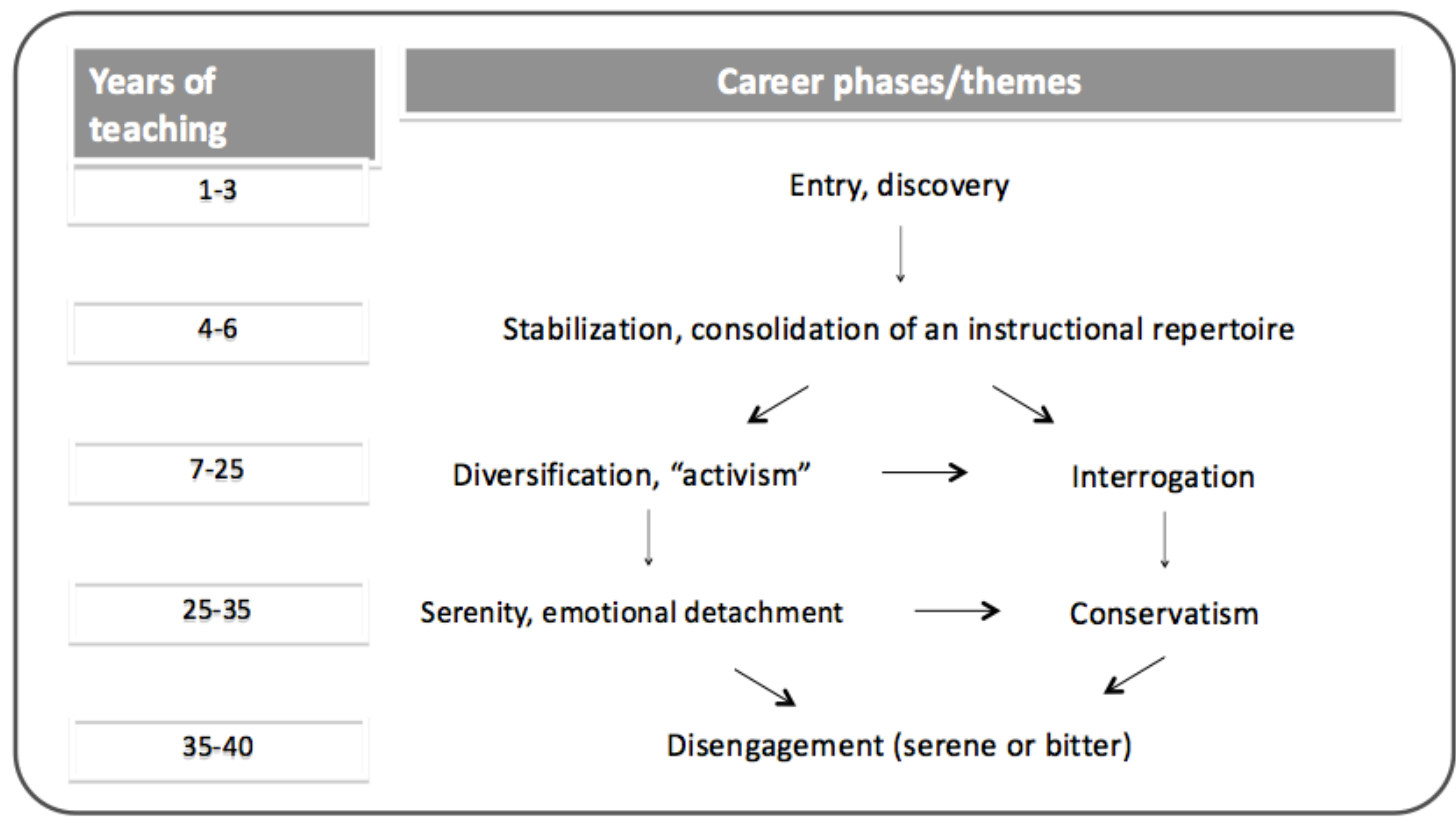

Source: Adapted from Huberman (2000, p. 47).

Figure 1 Teacher life cycle phases, Michel Huberman.

According to the author, career entry is a time of enthusiasm, of learning the reality of the profession and exploring the work environment. This implies a phase of discoveries, and it is common that the professional will experience a "reality shock". According to Huberman (2000), this phase lasts from 1 to 3 years.

Next, the teacher undergoes the stabilization phase, which is the degree-award stage, when the educator has more autonomy in his or her decisions, with formed opinions and greater responsibilities. Teacher stabilization means maturity in the profession. To Huberman (2000, p. 40), "stabilization slightly precedes or is followed by a feeling of growing educational 'competence". This phase covers the period from 4 to 6 years of professional work.

After the stabilization phase, the teacher begins to analyze all of the possibilities of his or her career, which is an experimentation and diversification phase. Teachers experiment with teaching strategies, such as diversifying both class material and student assessment models, and demonstrate confidence in changing the classroom layout, etc. The educator becomes more confident about his or her actions inside and outside the classroom. To Huberman (2000, p. 42), "teachers, at this stage of their careers, would be, thus, the most motivated, dynamic, enthusiastic members of educational teams." This phase is the one with the longest duration, starting at 7 years of work and extending to 25 years. 
This phase may, however, take additional forms. Instead of stabilization, it may become the interrogation stage, i.e., the teacher may start questioning his or her alternatives. To Huberman (2000, p. 43), "this is a phase with multiple facets, so trying to fit it to a correspondent reducing definition is a difficult, if not invalid task." This phase is also one in which the professional makes an assessment of his or her "life", of what has been achieved and what he or she intends to achieve; uncertainty about earlier professional choices is a constant in his or her decisions. In other words, this period can be marked by the pursuit of personal development and performance of administrative functions, by interrogation and reduced academic commitments.

The next phase will depend on the path taken by the teacher in the previous phase. If the teacher has experienced a "diversification" stage, the process of serenity and emotional detachment begins. The teacher begins to realize that he or she does not have the same energy as before and that his or her detachment from the school and its students is gradually increasing. Detachment between older teachers and students is often generated because they belong to different generations and age groups; this period is when dialogue becomes more di- fficult (Huberman, 2000). In contrast, if in the previous phase the teacher experienced an "interrogation" phase, the conservatism phase starts, in which regrets, nostalgia, and resistance to change are common. This period lasts between 25 and 35 years of teaching.

The final phase described by Huberman (2000) is disengagement, when the teacher is at the end of his or her professional life and lacks interest in new career investments. In summary, it is an evolution of previous trends and can be either a serene or a bitter phase, depending on the paths previously taken.

Since the studies of Huberman $(1989 ; 2000)$, the topic of professional life cycle has gained prominence in the academic community and other scholars have dedicated themselves to exploring it (e.g., Gonçalves, 2009; Jesus \& Santos, 2004; Veenman, 1984). According to Gonçalves (2009), a teaching career is a relational and contextual, empirical and formative trajectory in which a person-teacher will develop along stages or phases with unique characteristics. In his study, Gonçalves (2009) analyzes the professional paths of 42 teachers in the First Cycle of Basic Education of the Council of Olhão, Portugal, and drafts a career "path-type" consisting of five phases or stages, as depicted in Figure 2.

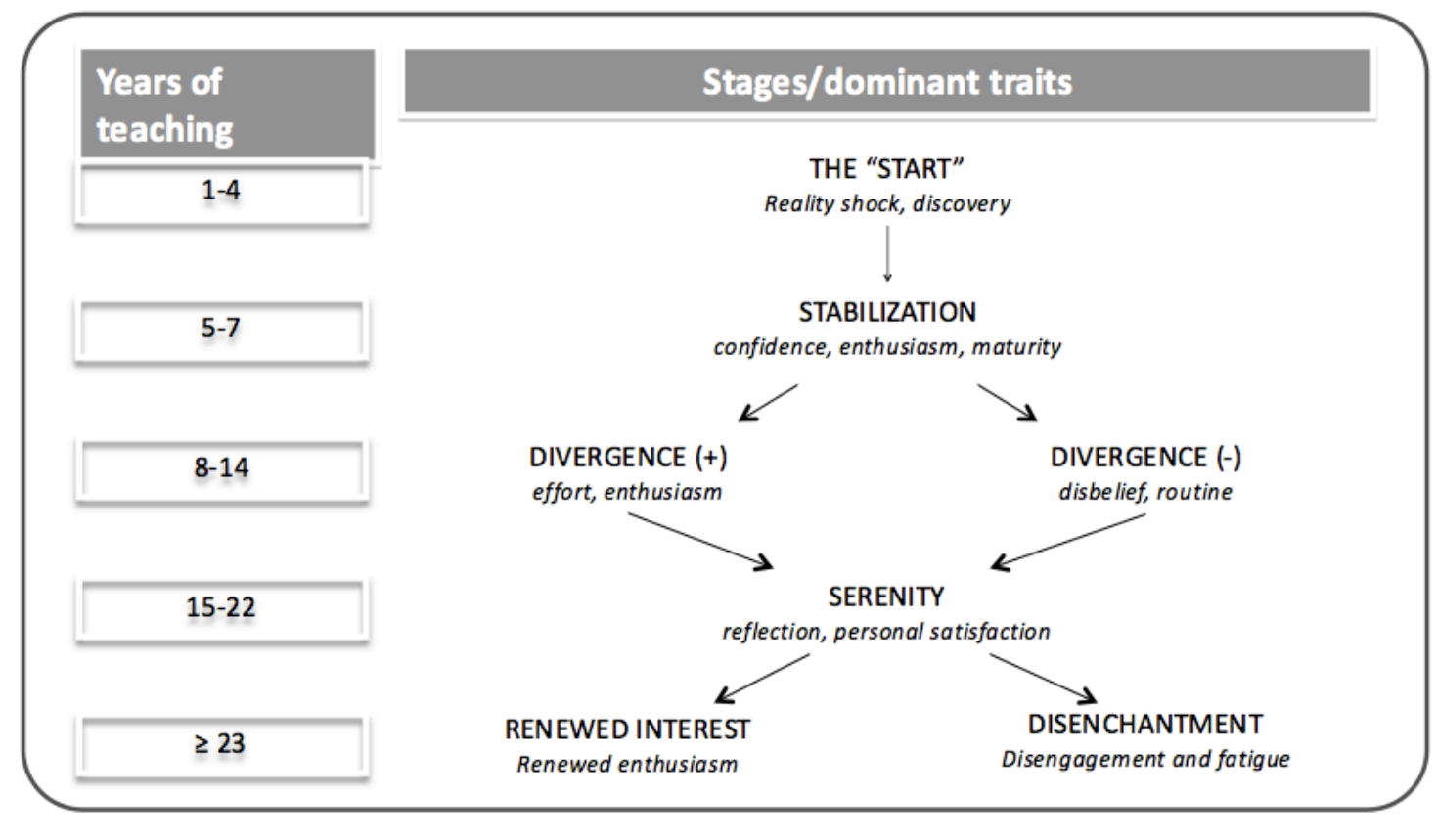

Source: Adapted from Gonçalves (2009, p. 438).

Figure 2 Teacher life cycle phases, José Alberto Gonçalves.

According to Gonçalves (2009), the first and second phases have the characteristics described by Huberman (2000), i.e., entry into the profession and its initial difficulties, followed by mastering teaching activities and stabilization in the profession. The duration of each of these two phases is also similar to that proposed by Huberman (2000), at 4 and 3 years, respectively.
In contrast, the third phase is characterized, according to Gonçalves (2009), as a stage of divergences, either positive or negative-i.e., some teachers may be committed and enthusiastic, whereas others may be disbelievers and tired of the routine. In Gonçalves (2009), the third phase lasts for only six years, which is much shorter than in Huberman (2000), in which this phase lasts for up to 18 years (Figure 1). 
The fourth phase of Huberman (2000) can involve two distinct positions: serenity and emotional detachment or conservatism. In Gonçalves (2009), in turn, the fourth phase is one of serenity and reflection.

The fifth phase is similar for the two authors, divided into renewed interest or disengagement for Gonçalves (2009), and serene or bitter for Huberman (2000). Again, in Gonçalves (2009), the length of the fourth and fifth phases is shorter than that presented by Huberman (2000).

Jesus and Santos (2004) performed a critical review of the main findings on teachers' life cycles. The authors emphasize that the beginning of a teaching career is considered by almost all scholars as the most important and potentially problematic stage, considering the implications of entry into the professional practice for the teacher's professional future in terms of perceived self-effectiveness and professional identity. In the beginning, a so-called "reality shock" may occur, which pits the concept of the idealized stereotype of the teaching profession acquired during initial training against the reality of everyday work in the classroom (Jesus \& Santos, 2004).

Even considering entry into the teaching profession as the most problematic and significant period in the professional path of the teacher, teachers can be more or less motivated at different periods of their careers, and it is possible to state that teaching career may be turbulent in several phases of the life cycle. Delgado, Fuentes, Quevedo, Salgado, Sánchez, Sanchez, Velasco, et al. (1993) highlight that the lack of practical training and excessive theoretical knowledge provided at institutions for the initial training of teachers are crucial factors in the teacher's "reality shock" or lack of motivation at the beginning of his or her career. However, most scholars in the field argue that it is not correct to state that all of teachers' early problems are associated with their initial training. According to Jesus and Santos (2004), many professionals are neither disappointed nor dissatisfied at the beginning of professional practice; on the contrary, they feel enthusiastic and happy .

\subsection{Teaching-Career Problems Perceived by Educators.}

There are several studies that address the problems confronted by educators along their career path (Huberman, 1989; Gonçalves, 2009; Jesus \& Santos, 2004; Masetto, 2010; Krasilchik, 2008; Cunha, 2009). However, Veenman (1984) takes a special approach, summarizing the findings of several previous studies; accordingly, this study focuses on his work.

Veenman (1984) reviews 83 studies from several countries, including the United States, West Germany, United Kingdom, Netherlands, Australia, Canada, Austria, Switzerland, and Finland. He investigates various aspects of those studies, such as geographic location, school level, number of subjects, and research method. The authors of the original studies reviewed used questionnaires in which respondents were asked to rate (on a point scale) the extent of the problem that was being analyzed. To complete the data, some authors conducted interviews with part of the sample.

According to Veenman (1984), problems are seen as difficulties that teachers encounter, especially early in their jobs, which might hinder the pursuit of their goals. Veenman (1984) cites authors who have already studied this subject, for example, Ryan (1979), Müller-Fohrbrodt, Cloetta and Dann (1978), Taylor and Dale (1971), and Lademann and Lietzke (1977). Most of those authors consider the beginning of a teacher's career as the most problematic stage, usually when beginning teachers are assigned heavy teaching loads, are asked to teach more difficult classes to students with higher levels of learning difficulties, or are assigned to teach subjects for which they not only lack adequate knowledge but also are improperly trained.

The 24 most critical problems identified in Veenman (1984) are shown in Figure 3.

\begin{tabular}{|l|l|l|l|}
\hline \multicolumn{2}{|l|}{ Problems presented by Simon Veenman } \\
\hline 1 & Classroom discipline & 13 & School policies (rules) \\
3 & Student motivation & 14 & Determining students' learning levels \\
4 & Assessing student's work & 15 & Mastering knowledge \\
5 & Relationship with parents & 16 & Excessive clerical work \\
6 & Organization of class work & 17 & Relationship with principals \\
7 & Insufficient materials & 18 & Inadequate school structure \\
8 & Addressing individual students' problems & 19 & Working with slow learners \\
9 & Heavy teaching load, insufficient prep time & 20 & Working with different students (cultures) \\
10 & Relationship with colleagues & 21 & Effective use of educational material \\
11 & Lesson planning & 23 & Lack of spare time \\
12 & Effective use of different methods & 24 & Inadequate guidance \\
\hline
\end{tabular}

Source: Adapted from Veenman (1984). 
In the review conducted by Veenman (1984), the most serious problem to confront teachers early in their careers is discipline in the classroom, however, he states that the conception of this problem can be interpreted in different ways, i.e., what is called discipline or order by one teacher may be called disorder by another and vice versa. Krasilchik (2008) clarifies that an experienced teacher's performance is critical for new students because teachers should establish an environment of respect, strictness, and love of studying, which will define students' relationship with school during their formative years.

The second most serious problem reported by Veenman (1984) is student motivation. He argues that in the early stages of their career, teachers find it more difficult to engage students, especially when they are unable to motivate those students in the teaching and learning process.

The next most serious problems are as follows: managing individual differences, assessing student work, and relationships with parents, which are in $3^{\text {rd }}, 4^{\text {th }}$, and $5^{\text {th }}$ places, respectively. Veenman indicates that managing individual differences is a problem because previous stu- dies have demonstrated that it is difficult to change curricular and instructional practices to accommodate differences among students. Krasilchik (2008, p. 14) states, "The increased number of seats leads to a high number of overcrowded classrooms, which further aggravates the difficulties faced by professors." He also states that many beginner classes are assigned to inexperienced teachers, who often lack the necessary preparation and training.

Assessing student work is characterized as the fourth most serious problem because accumulating reliable information and assessing student performance are problematic activities for teachers, especially when they are not prepared to do so. The fifth most serious problem found by Veenman (1984), the relationship with parents, has several aspects, with teachers in the early stages of their careers most often citing parents' lack of confidence in beginning teachers (this problem has little relevance to higher education, a focus of this study).

According to Veenman's (1984) analysis of the five major problems confronted by teachers at the beginning of their careers, teachers generally have greater difficulties with students, parents, and colleagues.

\section{METHODOLOGY}

This study is quantitative and is classified as descriptive because it aims to identify the main problems faced by professors both upon career entry and at later stages of their careers.

\subsection{The Instrument.}

The data-collection instrument used was the questionnaire, which was divided into two parts. The first asked the professionals about their career problems as professors and the intensity with which these problems affected their activity. A 10-point Likert scale was used, for which 1 indicated complete disagreement with the problem, i.e., it did not affect their activity, and 10 indicated total agreement with the problem, i.e., it fully affected their activity. The second part of the instrument aimed to gather information about the respondent's profile, such as gender, age, teaching experience.

The preparation of questions for the first part of the questionnaire was based on Veenman (1984). Considering that Veeman reviews studies of primary and secondary teachers, in this present study it was decided to submit the questions to a committee of 18 experts to validate the items' significance in the context of accounting courses. For this purpose, the Delphi technique (adapted) was used, which according to Vianna (1989, p. 42 ), is a method that "seeks to obtain consensus among experts based on anonymous answers to questionnaires and controlled feedback: it is, therefore, a structured way to obtain expert opinion".

The term expert means an individual with exceptional knowledge, experience, and a confirmed professional degree. Following the guidelines of this technique (according to Vianna, 1989; Roque, 1998; Giovinazzo, 2001; Czinkota \& Ronkainen, 2005; Grisham, 2009), the aim was to compose a committee that included both individuals employed by academic institutions and professionals involved in teaching accounting. Thus, researchers from both the education and accounting fields were invited, along with professors employed in the private sector, such as accountants, managers, and consultants.

Twenty-nine experts from various Brazilian regions were invited. Of these, only 18 completed all stages of the Delphi technique. Their training areas were as follows: accounting (13), administration (3), and education (2). This committee was established to provide a balanced panel of experts in terms of both impartiality and interest in the subject, as proposed by Grisham (2009).

The questions posed to the experts were available in free access electronic form (Google Docs), which facilitated contact with and the participation of the panel members.

To reach a consensus among the expert panel members on the items identified as problems in the profession of teaching accounting, two rounds of questions were submitted, the first in December 2012 and the second in January 2013. To determine the end of the rounds, the coefficient of variation of the responses was calculated (ratio between standard deviation and mean), which was classified as follows: (i) ratio lower than 15\%, low dispersion; (ii) ratio between $15 \%$ and $30 \%$, medium dispersion; (iii) ratio higher than $30 \%$, high dispersion (Martins \& Theóphilo, 2007). At the end of the second round, all of the items reached coefficients of variation lower than $30 \%$. 
To define the validated items, the acceptability level of the items was considered after the second round (Cunha, 2007). The items were divided into two groups: (i) low acceptability items, i.e., those that obtained less than 50\% agreement among experts; (ii) medium and high acceptability items, i.e., those that obtained $50 \%$ or more agreement among the experts.

Among the 24 items identified by Veenman (1984) (Figure 2), 11 were validated because they had medium or high acceptability. In addition to informing the degree of agreement with the items, the experts made suggestions to change the wording of the evaluated items to adapt them to Brazil's higher education context. Below, the 11 validated items are presented with their respective percentages of agreement (right) and reference to the original item in Veenman (1984) (original item number on the left):

1) Lack of student discipline (57\%);

2) Lack of student motivation (57\%);

3) Heterogeneous classes (54\%);

4) Difficulty in determining learning level (54\%);

9) Lack of time (58\%);

12) Mastering different teaching methods (52\%);

13) Knowledge of academic standards (52\%);

15) Lack of conditions for additional training (58\%);

16) Amount of administrative work (61\%);

20) Very large class sizes (56\%);

23) Lack of guidance by the higher education institution (HEI) (51\%).

After defining the items through the Delphi technique, the questionnaire was completed and the data collection process began.

\subsection{Data Collection.}

Before submitting the questionnaire, two procedures were performed to identify and contact the research subjects: (i) survey of the e-mail addresses of the program coordinators in the Ministry of Education database (2012), complemented by research on the websites of HEI with accounting sciences programs. After the survey, electronic messages were sent (via personalized direct mail) to the program coordinators with a forwarding request to the program professors; (ii) during the visit to HEI campuses, the e-mail addresses of the professors were collected whenever such information was available, which was almost always the case at public HEIs. When only the names of the professors of the HEI were found, new Internet searches were performed to identify their e-mail addresses. Upon completion of this second survey, electronic messages were sent (via personalized direct mail) to the professors themselves.

Thus, 2,321 messages were sent to institutions and professors in three separate submissions at one-week intervals. Respondents received new messages thanking them for their participation. The questionnaire was built using Google Docs. The instrument was available for responses for slightly more than one month (from January 7 to February 8, 2013). During this period, 574 valid responses were obtained.

\subsection{Data Analysis.}

First, the responses were consolidated and then, the characteristics of the sample were analyzed using descriptive statistics (gender, region of origin, degree, type of institution, age and teaching experience) for identification of each professor's stage in the life cycle.

Subsequently, the means of each problem were calculated according to the professorial life cycle stage. Problems were considered major when the mean was equal to or higher than 5 points on a scale from 1 to 10 . The same criterion was used to identify the problems that most afflict the professors in the different stages that make up the professional life cycle.

To compare the problems confronted by the professors according to degrees and type of institution (public or private), the nonparametric Mann-Whitney $U$ test was used because the data distribution was non-normal $(\mathrm{p}<0.05)$ according to the Kolmogorov-Smirnov and Shapiro-Wilk tests.

\section{RESULTS AND DISCUSSION}

The sample consisted of 574 professors. Of these, 191 (33\%) were female and 383 (67\%) were male. These results are consistent with other studies that show a predominance of males in the accounting field. In 2011, according to the Brazilian Federal Accounting Council (Conselho Federal de Contabilidade-CFC), the total number of certified accountants and accounting technicians registered with the agency was 487,717; of these, approximately $59 \%$ are male and $41 \%$ are female.

With respect to the respondents' professional degrees, there was a predominance of master's degrees (293), corresponding to $51 \%$ of the total sample. There were $161(28 \%)$ professors with doctoral degrees, with 7 professors having completed postdoctoral studies. There were $112(20 \%)$ professors with the highest specialist degree or with MBAs. Eight of the respondents (1\% of the sample) had only an undergraduate degree .

It was also observed that $47 \%$ of respondents have one or more occupations in addition to teaching, i.e., more than half the sample (53\%) has no occupation other than teaching accounting. This suggests that most of the respondents may be solely dedicated to their teaching practice at HEIs. Ano- 
ther factor that reinforces this possibility relates to the type of HEI for which the professor works. It was found that 330 respondents (57\%) teach at public institutions and $43 \%$ teach at private institutions. In this regard, the sample does not depict Brazilian reality because the number of private institutions is much higher than the number of public institutions (therefore, separate analyses are performed in Table 4). It is also important to mention that in general, public HEIs provide their professors' e-mail addresses on their websites, which most likely increased the likelihood that professors at public HEIs received the questionnaire.

The Southeast region had the highest number of respondents (34\%), which is explained by the presence of a higher number of higher education institutions in the re- gion. São Paulo was the state with the highest number of respondents (18\%). The participation of professors from the Southern region represented $28 \%$ of the sample, with the participation of each of the three states of the region (Paraná, Santa Catarina, and Rio Grande do Sul) at approximately $9 \%$ each. The Northeast region ranked third, comprising $20 \%$ of the sample, and the state of Paraíba had the highest number of respondents in the region (5.2\%). Professors in the Central-West region totaled 14\% of the sample. Respondents from the Northern region only accounted for $4 \%$ of the sample. Only the states of Acre, Amapá, and Maranhão had no respondents.

Table 1 shows the sample distribution by life cycle phase, as proposed by Huberman (2000).

Table 1

Characteristics of respondents according to years of teaching

\begin{tabular}{|c|c|c|c|}
\hline Years of teaching & Life cycle stage & Quantity & Percentage \\
\hline 1 to 3 years & Entry & 83 & $15 \%$ \\
\hline 4 to 6 years & Stabilization & 77 & $13 \%$ \\
\hline 7 to 25 years & Diversification or Interrogation & 357 & $62 \%$ \\
\hline 26 to 35 years & Serenity or Conservatism & 46 & $8 \%$ \\
\hline More than 35 years & Disengagement & 11 & $2 \%$ \\
\hline Total & & 574 & $100 \%$ \\
\hline
\end{tabular}

Source: Authors.

The sample consisted of professors from all of the life cycle phases proposed by Huberman (2000). The phase with the highest number of respondents $(62 \%)$ is the diversification or experimentation phase, which is also the longest phase, starting at 7 years of experience and exten- ding to 25 years of experience. It can also be observed that $28 \%$ of the sample has up to 6 years of teaching experience and $10 \%$ have more than 25 years of experience.

The analysis of the gender distribution at each phase reveals surprising changes over time, as shown in Figure 4.

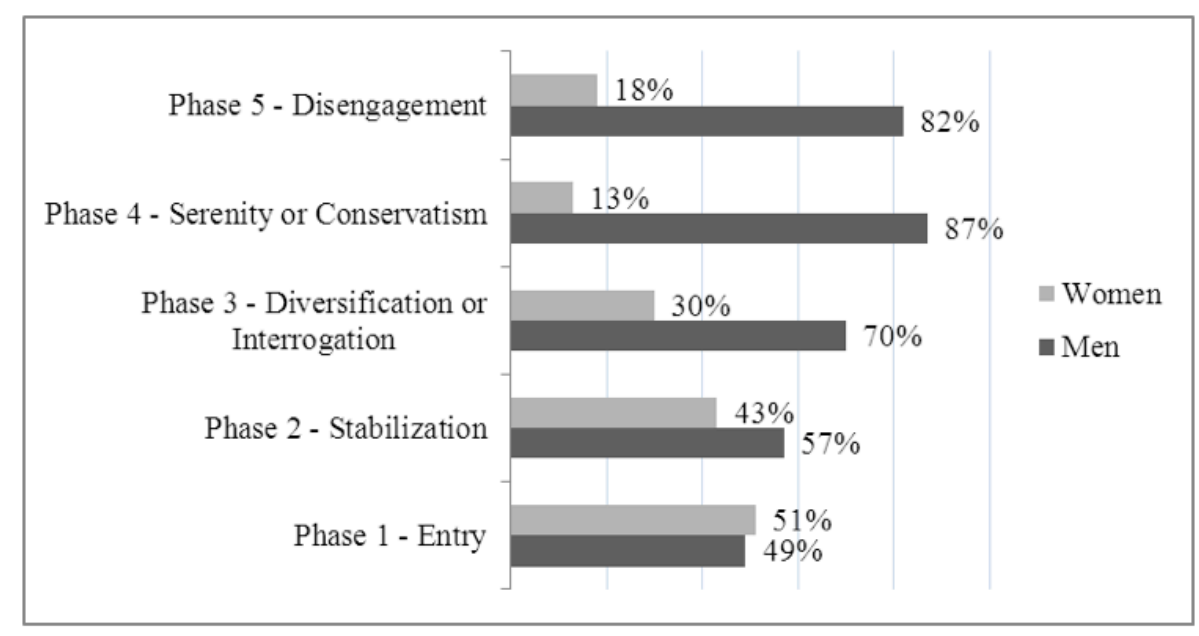

Source: Authors.

Figure 4 Gender of respondents in each life cycle phase.

In phase 5, which contains respondents with 35-40 years of practice and that is therefore the phase with the most experienced professors, $82 \%$ of respondents are male. Similarly, in phase 4 (25 to 35 years of teaching), $87 \%$ of respondents are male. In phase 3 , whose res- pondents have 7-25 years of teaching, the presence of females increase to $30 \%$. In phase 2 , which includes professors with 4-6 years of professional experience, females represent $43 \%$ of the professors surveyed. Finally, in phase 1 , which represents professors in the early career 
stages (1-3 years), there is a reversal in the predominant gender: $51 \%$ of the sampled professors are female. This change in terms of gender is the result of a higher number of women in higher education, especially in accounting sciences programs.
Table 2 shows the mean scores of each of the problems experienced by the study participants during each of the life-cycle phases proposed by Huberman (2000), i.e., it describes the intensity with which each problem affects the respondents.

Table 2 Mean score of problems faced by professors in each life cycle phase

\begin{tabular}{|c|c|c|c|c|c|c|}
\hline Variable & Mean & $1^{\text {st }}$ Phase & $2^{\text {nd }}$ Phase & $3^{\text {rd }}$ Phase & $4^{\text {th }}$ Phase & $5^{\text {th }}$ Phase \\
\hline 1) Lack of student motivation & 6.06 & 6.58 & 6.22 & 6.06 & 5.33 & 4.18 \\
\hline 2) Heterogeneous classes & 5.90 & 6.43 & 5.95 & 5.82 & 5.76 & 4.45 \\
\hline 3) Amount of administrative work & 5.51 & 5.30 & 5.10 & 5.82 & 4.39 & 4.73 \\
\hline 4) Very large class sizes & 5.44 & 5.98 & 5.66 & 5.31 & 5.30 & 4.55 \\
\hline 5) Lack of time & 5.16 & 5.55 & 4.94 & 5.14 & 5.24 & 4.00 \\
\hline 6) Difficulty in determining learning level & 4.98 & 5.43 & 4.74 & 5.00 & 4.83 & 3.00 \\
\hline 7) Lack of conditions for additional training & 4.84 & 4.96 & 5.97 & 4.67 & 4.50 & 3.09 \\
\hline 8) Lack of HEI guidance & 4.82 & 5.24 & 4.35 & 4.95 & 4.07 & 3.91 \\
\hline 9) Lack of student discipline & 4.44 & 4.57 & 4.73 & 4.46 & 3.89 & 3.09 \\
\hline 10) Mastering different teaching methods & 4.40 & 5.16 & 4.25 & 4.31 & 4.26 & 3.27 \\
\hline
\end{tabular}

Source: Authors.

According to Table 2, the main problems for the studied sample are: (1) lack of student motivation; (2) heterogeneous classes; (3) amount of administrative work; (4) very large class sizes; and (5) lack of time.

The problem with the highest mean (6.06) was "lack of student motivation." This result corroborates the findings of Veenman (1984), according to which student motivation appears as the second-largest problem faced by teachers. Next, "heterogeneous classes" appears as the second problem identified by the respondents, with a mean of 5.90. Again, this finding is in accordance with Veenman (1984), where this problem was ranked third. Heterogeneity, or diversity, is greater today due to Brazil's expansion of access to higher education in recent decades. According to Cunha and Pinto (2009), changes that have affected the university imply the admission of students with increasingly diverse backgrounds, with respect to both culture and prior education, motivations, and expectations. Class size, which is related to the diversity problem (overcrowded classrooms), ranked fourth, with a mean of 5.44 .

Third, we see "amount of administrative work", with a mean of 5.51 points. At HEIs in general, professors assume numerous roles or perform numerous activities in addition to teaching (coordinator, director, supervisor, research projects, outreach projects, committees, examining boards, process reports, guidance, etc.). "Lack of time" is also associated with the amount of administrative work, with a mean of 5.16, the fifth-largest problem identified by professors.

In addition to identifying the main overall problems, this study aimed to identify the biggest problems encountered at each of the phases that comprise the professional life cycle proposed by Huberman (2000). For this aspect, it was interesting to note that the ranking of the problems tends to be practically the same during all five phases.

In the first phase, entry into the profession, the main problems faced by professors are the same as in the overall ranking, with the addition of one problem: "6) Difficulty in determining the learning level". This is also the phase during which problems had the highest means, i.e., when professors perceived problems with the most intensity. This is the time during which professors are subject to "reality shock" (Huberman, 2000).

In the second phase, the item "lack of time" was not among the main problems, with another item in evidence, namely, "lack of conditions for additional training". Thus, it is noted that professors with between 4 and 6 years of teaching experience difficulties in completing their graduate studies. This is understandable in the accounting field because Brazil has few graduate programs.

In the third phase, which is the longest of the five and lasts from 7 to 25 years of practice, the top five problems identified in the overall rank are retained and one is added: "difficulty in determining the learning level", which obtained a mean of 5 points. It is noted that during this period of diversification and experimentation, professors both seek methods of establishing appropriate assessment methods and perceive this search as inconvenient.

In the fourth phase, a period of serenity and conservatism, only four problems appear as relevant, namely, lack of student motivation, heterogeneous classes, very large sizes, and lack of time.

Finally, in the fifth phase, during which professors enter the retirement process (disengagement), no problem seems to be important to professors, because all of 
those problems had mean scores below $50 \%$, i.e., below 5 points. Moreover, it is worth noting that the importance of problems tends to decrease in each of the five phases, as evidenced in Figure 5.

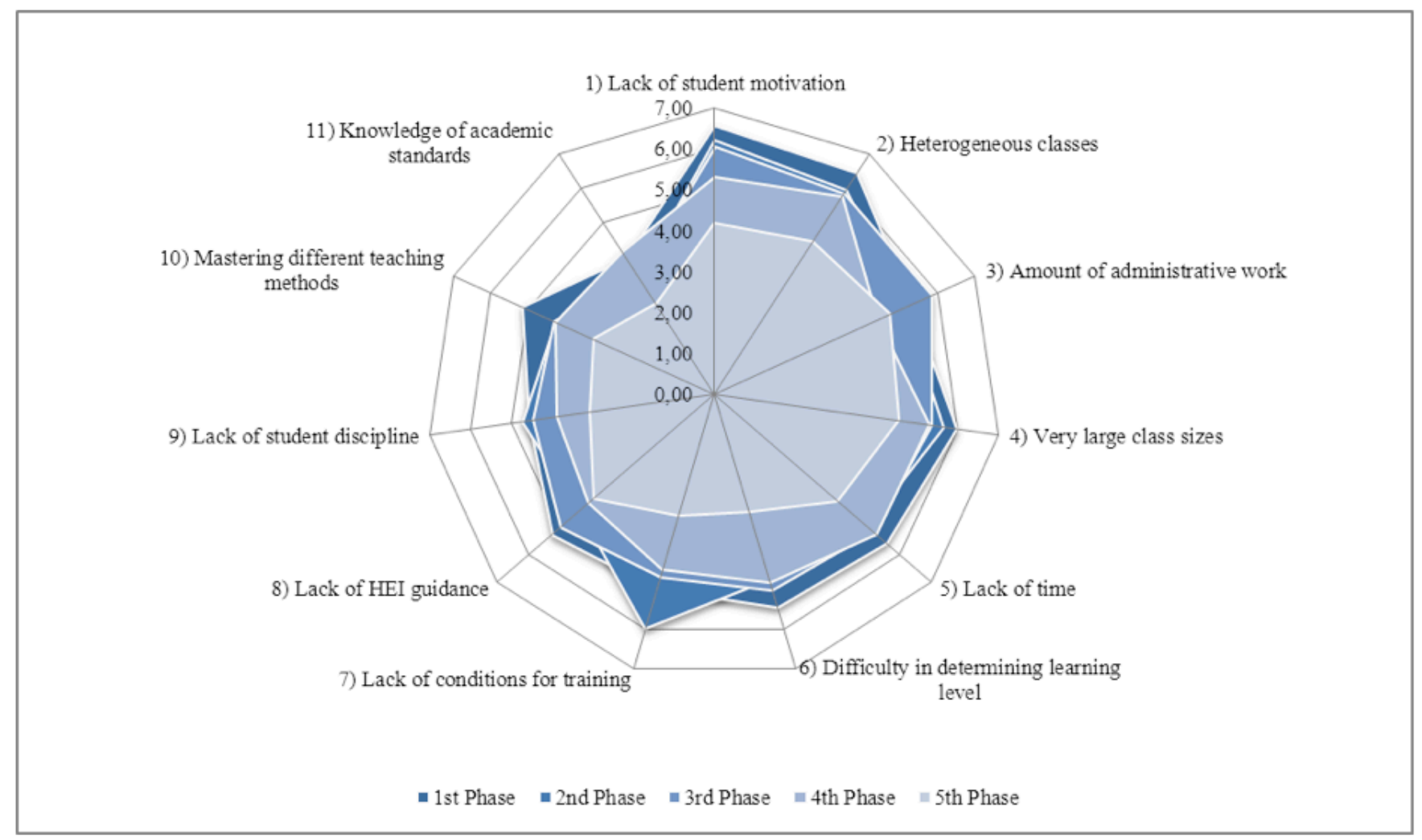

Source: Authors.

Figure $5 \quad$ Problems perceived by professors during each life-cycle phase

Figure 5 demonstrates that the beginning of the professional career is potentially the most problematic phase because it is the period during which "reality shock" occurs; i.e., it is when professors face problems such as lack of acceptance and preparation for teaching practice. These findings corroborate the argument of several authors (Ryan, 1979; Müller-Fohrbrodt et al., 1978; Tayor \& Dale, 1971; Lademann \& Lietzke, 1977; Jesus \& Santos, 2004).

After the career entry phase, professors gradually overcome these problems, i.e., they begin to accumulate so-called experiential knowledge, as advocated by another group of authors in the education field (Tardif, 2000; Pimenta \& Anastasiou, 2002; Gauthier, Martineau, Desbiens, Malo, \& Simard, 1998).

This study also analyzed whether the perception of professors who work at public institutions is different from the perception of professors who work at private institutions. Thus, the median test was performed, as shown in Table 3.

Table 3

Comparison of medians between professors of public and private institutions

\begin{tabular}{lccccccccccc}
\hline Test/variable & $\begin{array}{c}\text { 1) } \\
\text { Motiv. }\end{array}$ & $\begin{array}{c}\text { 2) } \\
\text { Heterog. }\end{array}$ & $\begin{array}{c}\text { 3) Adm. } \\
\text { work }\end{array}$ & $\begin{array}{c}\text { 4) Class } \\
\text { size }\end{array}$ & $\begin{array}{c}\text { 5) Time } \\
\text { Learning } \\
\text { level }\end{array}$ & $\begin{array}{c}\text { 6) } \\
\text { Training }\end{array}$ & $\begin{array}{c}\text { 8) HEI } \\
\text { guidance }\end{array}$ & $\begin{array}{c}\text { 9) } \\
\text { Discipline }\end{array}$ & $\begin{array}{c}\text { 10) } \\
\text { Teaching } \\
\text { meth. }\end{array}$ & $\begin{array}{c}\text { 11) } \\
\text { Standards }\end{array}$ \\
\hline Mann-Whitney $U$ & 38,745 & 36,717 & 34,877 & 38,389 & 39,131 & 38,156 & $38,967.5$ & $32,414.5$ & 37,479 & 39,002 & 39,459 \\
$p$ (two-tailed) & 0.437 & 0.070 & 0.006 & 0.338 & 0.563 & 0.281 & 0.505 & 0.000 & 0.154 & 0.518 & 0.678 \\
\hline
\end{tabular}

Source: Authors.

As can be observed, only the variables " 3 ) amount of administrative work" and "8) lack of HEI guidance" have significantly different medians depending on whether the employing institution is public or private, at a $5 \%$ significance level. In fact, the amount of administrative work at public institutions tends to be higher because these institutions also have the highest number of professors who work for them exclusively and who perform tasks related to teaching, research, outreach, and primarily administrative activities. Likewise, lack of guidance also appears to be greater in public HEIs, perhaps because the decision-making process is less centralized. 
This study also aimed to analyze the problems perceived by professors according to the professional degrees held by those professors. Considering that professors who had only earned an undergraduate degree and professors with postdoctoral experience represented approximately $1 \%$ of the sample, the degrees were clustered into three groups, namely: (i) specialists, i.e., professors with no more than a specialist degree; (ii) masters, i.e., professors with a master's degree; and (iii) doctors, i.e., professors with either a doctoral degree or postdoctoral experience.

Table 4 shows the comparison between the problems faced by professors with no more than a specialist degree and those with master's degrees.

Table 4 Comparison of medians between professors with specialist and master's degrees

\begin{tabular}{|c|c|c|c|c|c|c|c|c|c|c|c|}
\hline Test/variable & $\begin{array}{l}\text { 1) } \\
\text { Motiv. }\end{array}$ & $\begin{array}{c}\text { 2) } \\
\text { Heterog. }\end{array}$ & $\begin{array}{l}\text { 3) Adm. } \\
\text { work }\end{array}$ & $\begin{array}{l}\text { 4) Class } \\
\text { size }\end{array}$ & 5) Time & $\begin{array}{c}\text { 6) } \\
\text { Learning } \\
\text { level }\end{array}$ & 7) Training & $\begin{array}{c}\text { 8) } \mathrm{HEI} \\
\text { guidance }\end{array}$ & $\begin{array}{c}\text { 9) } \\
\text { Discipline }\end{array}$ & $\begin{array}{c}\text { 10) } \\
\text { Teaching } \\
\text { meth. }\end{array}$ & $\begin{array}{c}\text { 11) } \\
\text { Standards }\end{array}$ \\
\hline Mann-Whitney U & 14,672 & $16,599.5$ & $15,022.5$ & 15439.5 & $14,713.5$ & $15,298.5$ & $16,343.5$ & 14,959 & 15,537 & $15,624.5$ & $16,350.5$ \\
\hline p (two-tailed) & 0.008 & 0.370 & 0.019 & 0.050 & 0.009 & 0.037 & 0.257 & 0.017 & 0.062 & 0.074 & 0.258 \\
\hline
\end{tabular}

Source: Authors.

The data reveal that the perception of some problems is significantly different between professors with master's and specialist degrees. It is noted that professors with master's degrees are more affected by the following problems: "1) lack of student motivation"; "3) amount of administrative work"; "4) very large class sizes"; "5) lack of time"; "6) difficulty in determining learning level"; and "8) lack of HEI guidance". These results seem to contradict the trend shown in Table 2 because in principle, it is assumed that professors with specialist degrees are in a life-cycle stage that is earlier than that of professors with master's degrees. However, when the ave- rage age of professors is observed in light of their degrees, it is noted that approximately $70 \%$ of professors with master's degrees are aged between 31 and 50 years old and only 56\% of specialists are in the same age group. In other words, it is likely that there are more professors with master's than specialist degrees in the early phases of the life cycle, therefore, these professors are more susceptible to problems related to career entry (Huberman, 2000).

Table 5 shows the comparison between the problems faced by professors with no more than a specialist degree and those with at least a doctoral degree.

Table 5 Comparison of medians between professors with specialist and doctoral degrees

\begin{tabular}{lccccccccccc}
\hline Test/variable & $\begin{array}{c}\text { 1) } \\
\text { Motiv. }\end{array}$ & $\begin{array}{c}\text { 2) } \\
\text { Heterog. }\end{array}$ & $\begin{array}{c}\text { 3) Adm. } \\
\text { work }\end{array}$ & $\begin{array}{c}\text { 4) Class } \\
\text { size }\end{array}$ & 5) Time & $\begin{array}{c}\text { 6) Learning } \\
\text { level }\end{array}$ & $\begin{array}{c}\text { 7) } \\
\text { Training }\end{array}$ & $\begin{array}{c}\text { 8) HEI } \\
\text { guidance }\end{array}$ & $\begin{array}{c}\text { 9) } \\
\text { Discipline }\end{array}$ & $\begin{array}{c}\text { 10) Teaching } \\
\text { meth. }\end{array}$ & $\begin{array}{c}\text { 11) } \\
\text { Standards }\end{array}$ \\
\hline Mann-Whitney U & 8,844 & $8,631.5$ & 7,670 & $9,349.5$ & $8,236.5$ & 9,367 & $5,854.5$ & 8,160 & 9,648 & $9,033.5$ & $8,215.5$ \\
Sig. (two tailed) & 0.223 & 0.125 & 0.003 & 0.642 & 0.033 & 0.662 & 0.000 & 0.025 & 0.986 & 0.347 & 0.028 \\
\hline
\end{tabular}

Source: Authors.

The data show that five problems have significantly different perceptions among professors with no more than a specialist degree and professors with at least a doctoral degree. Doctors are more affected than the specialists by the following problems: "3) amount of administrative work" and "5) lack of time", which is understandable within Brazil's accounting context due to the low number of doctors in the field available to perform activities related to teaching (undergraduate and graduate courses), research, outreach, and administrative activities.
In contrast, specialists are more affected than doctors by the following problems: "7) lack of conditions for additional training"; "8) lack of HEI guidance"; and "11) knowledge of academic standards." As can be observed, these are problems that affect professors in the early phases of the professional life cycle, who have not completed their graduate studies, and who seek stability in the teaching profession.

Finally, Table 6 shows the comparison between the problems experienced by professors with no more than a master's degree and professors with at least a doctoral degree.

Table 6 Comparison of medians between professors with master's and doctoral degrees

\begin{tabular}{|c|c|c|c|c|c|c|c|c|c|c|c|}
\hline Test/variable & $\begin{array}{c}\text { 1) } \\
\text { Motiv. }\end{array}$ & $\begin{array}{c}\text { 2) } \\
\text { Heterog. }\end{array}$ & $\begin{array}{l}\text { 3) Adm. } \\
\text { work }\end{array}$ & $\begin{array}{l}\text { 4) Class } \\
\text { size }\end{array}$ & 5) Time & $\begin{array}{c}\text { 6) } \\
\text { Learning } \\
\text { level }\end{array}$ & $\begin{array}{c}\text { 7) } \\
\text { Training }\end{array}$ & $\begin{array}{c}\text { 8) } \mathrm{HEI} \\
\text { guidance }\end{array}$ & $\begin{array}{c}\text { 9) } \\
\text { Discipline }\end{array}$ & $\begin{array}{c}\text { 10) } \\
\text { Teaching } \\
\text { meth. }\end{array}$ & $\begin{array}{c}\text { 11) } \\
\text { Standards }\end{array}$ \\
\hline Mann-Whitney $U$ & $22,124.5$ & $19,422.5$ & $21,632.5$ & 19,701 & $23,358.5$ & $19,838.5$ & 15,675 & 23,330 & 21,030 & 19,597 & 18,700 \\
\hline p (two tailed) & 0.271 & 0.002 & 0.142 & 0.003 & 0.864 & 0.005 & 0.000 & 0.847 & 0.054 & 0.003 & 0.000 \\
\hline
\end{tabular}


According to Table 6, professors with master's degrees are more affected than those with doctoral degrees by six problems: "2) heterogeneous classes"; "4) very large class sizes"; "6) difficulty in determining learning level”; "7) lack of conditions for additional training"; "10) mastering different teaching methods"; and "11) knowledge of academic standards". It is noted that these are problems primarily re- late to career entry and the lack of additional training for teaching practice. These results are consistent with the data presented in Table 2, where it can be observed that these problems affect professors less as they reach the later phases of the life cycle. In other words, professors with doctoral degrees are certainly at more advanced life-cycle stages than those with master's and specialist degrees.

\section{CONCLUSIONS}

This study identified the main problems faced by professors both upon career entry and at later stages. The findings revealed that the problems experienced by accounting professors are very similar to those identified by Veenman (1984), with career entry being the most critical phase. The main problems identified in the career entry phase were the following: (1) lack of student motivation; (2) heterogeneous classes; (3) amount of administrative work; (4) very large class sizes; (5) lack of time; and (6) difficulty in determining learning levels.

When problems are analyzed according to professors' degrees, lack of additional training, lack of guidance by the HEI, and knowledge of academic standards are problems that most directly affect professors with lower professional degrees, whereas lack of time and large amounts of administrative work are the problems that are experienced more intensely by professors with higher degrees.

These findings suggest the need for educational training of accounting professors to overcome the problems that afflict those entering the profession. It is necessary for professors to understand academic standards and to have access to guidance from their HEIs. It is also important for these professionals not only to have training that in addressing student diversity but also to have the tools to motivate students.

The large amount of administrative activity and the lack of time indicated by professors with higher degrees is also a concern. In this regard, it is important to mention that because Brazil has few graduate programs in accounting, few professors hold doctoral degrees. Therefore, it is possible that those professors are overburdened. Thus, it is important for Brazil to maintain its policy to expand graduate programs.

The next step is to perform an in-depth assessment of the "reality shock" phenomenon experienced by professionals entering the field, to analyze whether the "disengagement" phase is serene or bitter in the accounting field, and to analyze whether professors' choices throughout their careers lead to one or another form of disengagement. 


\section{References}

Cunha, J. V. A. (2007). Doutores em ciências contábeis da FEA/USP análise sob a óptica da teoria do capital humano (Tese de Doutorado). Faculdade de Economia, Administração e Contabilidade, Universidade de São Paulo, São Paulo.

Cunha, M. D., \& Pinto, M. M. (2009). Qualidade e Educação Superior no Brasil e o desafio da inclusão social na perspectiva epistemológica è ética. Revista Brasileira de Estudos Pedagógicos, 90(226), 571-591.

Cunha, M. I. (2009). Trajetórias e lugares da formação do docente da Educação Superior: do compromisso individual à responsabilidade institucional. Revista Brasileira de Formação de Professores, I(1), 110128.

Czinkotä, M. R., \& Ronkainen, I. A. (2005). International business and trade in the next decade: report from a Delphi study. Journal of International Business Studies, 40(4), 111-123.

Delgado, A. C., Fuentes, J. M. B., Quevedo, M. P. A., Salgado, A. R., Sánchez, A. C., Sanchez, T. S., Velasco, C. A., et al. (1993). Revisión teórica del burnout o desgaste profesional en trabajadores de la docencia. Caesura, 2(2), 47-65.

Gauthier, C., Martineau, S., Desbiens, J. F., Malo, A., \& Simard, D. (1998) Por uma teoria da pedagogia: pesquisas contemporâneas sobre o saber docente. Ijuí, RS: Unijuí.

Giovinazzo, R. (2001). Modelo de aplicação da técnica Delphi pela internet: vantagens e ressalvas. Recuperado de http://www.fecap.br/ adm_online/art22/renata.htm

Gonçalves, J. A. (2009). Desenvolvimento profissional e carreira docente: fases da carreira, currículo e supervisão. Sísifo: Revista de Ciências da Educação, 8, 23-36

Grisham, T. (2009). The Delphi technique: a method for testing complex and multifaceted topics. International Journal of Managing Projects in Business, 2(1), 112-130.

Huberman, M. (1989). Le cycle de vie profissionnelle des enseignants secondaires. Résumé d’une recherche démentielle (Cahiers de la Section des Sciences de l'Education). Genève: Université de Genève.

Huberman, M. (2000). O ciclo de vida profissional dos professores. In A. Nóvoa (Org.), Vida de professores (2a ed.; pp. 31-61). Porto: Porto Ed.

Jesus, S. N., \& Santos, J. C. V. (2004). Desenvolvimento profissional e motivação dos professores. Educação, 27(1), 39-58.

Krasilchik, M. (2008, Maio): Docência no Ensino Superior: tensões e mudanças (Cadernos de Pedagogia Universitária USP, n. 12). São Paulo: Universidade de São Paulo.

Lademann, R. H., \& Lietzke, H. (1977). Zur Berufssituation des Lehrers jungen. Zeitschrift pele erziehungswissenschaftliche Forschung, 11, 155-161.

Martins, G. A., \& Theóphilo, C. R. (2007). Metodologia da investigação científica para ciências sociais aplicadas. São Paulo: Atlas.

Masetto, M. T. (2010, Maio). Docência no Ensino Superior voltada para a aprendizagem faz a diferença (Cadernos de Pedagogia Universitária USP, n. 12). São Paulo: Universidade de São Paulo.

Ministério da Educação. (2012). Plataforma e-MEC. Sistema e-MEC Recuperado de http://emec.mec.gov.br/

Miranda, G. J. (2011). Relações entre as qualificações do professor e o desempenho discente nos cursos de graduação em Contabilidade no Brasil (Tese de Doutorado). Faculdade de Economia, Administração e Contabilidade, Universidade de São Paulo, São Paulo.

Müller-Fohrbrodt, G., Cloetta, B., \& Dann, H. D. (1978). Der Praxisschock bei junger Lehrern. Stuttgart: Klett:

Nóvoa, A. (1992). Formação de professores e profissão docente. Lisboa: Dom Quixote.

Pierre, K. S., Wilson, R. M. S., Ravenscroft, S. P., \& Rebele, J. E. (2009, May). The role of accounting education research in our discipline: an editorial. Issues in Accounting Education, 24(2), 112-130.

Pimenta, S. G., \& Anastasiou, L. G. C. (2002). Docência no Ensino Superior São Paulo: Cortez.

Roque, R. F. (1998). Estudo comparativo de metodologias de desenvolvimento de sistemas de informação utilizando a técnica Delphi (Disșertação de Mestrado). Univerșidade Federal de Santa Catarina, Florianópolis, Brasil.

Ryan, K. (1979). Para a compreensão do problema: no liminar da profissão In K. R. Howey, \& R. H. Bents (Ed.), Para satisfazer as necessidades do professor iniciante. [S.1.]: [s.n.].

Tardif, M. (2000). Saberes profissionais dos professores e conhecimentos universitários. Elementos para uma epistemologia da prática profissional dos professòres e suas consequências em relação à formação para o magistério. Revista Brasileira de Educação, 13, 5-24.

Taylor, J. K., \& Dale, I. R. (1971). Uma pesquisa de professores em séu primeiro ano de serviço. Bristol: Universidade de Bristol.

Veenman, S. (1984). Perceived problems of beginning teachers. Review of Educational Research, 54(2), 143-178.

Vianna, N. W. H. (1989). Subjetividade no processo de previsão (Tese de Doutorado). Faculdade de Economia, Administração e Contabilidade, Universidade de São Paulo, São Paulo.

Zabalza, M. A. (2007). O ensino universitário. Porto Alegre: Artmed. 